\title{
A Study of Flexible Working Hours and Motivation
}

\author{
Abd. Rahman Ahmad ${ }^{1}$, Mohammad Talha Mohamed Idris $^{2} \&$ Mohd Hilmi Hashim $^{1}$ \\ ${ }^{1}$ Faculty of Technology Management and Business, Universiti Tun Hussein Onn Malaysia, Malaysia \\ ${ }^{2}$ Faculty of Science, Technology and Human Development, Universiti Tun Hussein Onn Malaysia, Malaysia \\ Correspondence: Abd. Rahman Ahmad, Faculty of Technology Management and Business, Universiti Tun \\ Hussein Onn Malaysia, 86400 Batu Pahat, Johor, Malaysia. Tel: 60-7-453-3952. E-mail: arahman@uthm.edu.my
}

Received: December 24, 2012 Accepted: January 21, 2013 Online Published: February 28, 2013

doi:10.5539/ass.v9n3p208

\author{
URL: http://dx.doi.org/10.5539/ass.v9n3p208
}

\begin{abstract}
The flexible working hours allows employees to focus on multiple roles in today's competitive working environments. This arrangement has been widely practiced in order to create balance between work and lifestyle. The purpose of this paper is to investigate the relationship between the flexible working hours and employees' motivation. The survey questionnaires were used for data collection in this study. Meanwhile, both descriptive and inferential statistics were employed to analyse the data. The results indicated that the implementation of flexible working hours show a significant impact to the employees' motivation in the XYZ Department. Thus, the null hypothesis was rejected. Therefore it can be concluded that there is a high positive correlation between flexible working hours and employees' motivation. Through this study, opinions, suggestions and comments were discussed to enhance the effectiveness of the working system.
\end{abstract}

Keywords: flexible working hours, motivation, job satisfaction

\section{Introduction}

Streamlining of working hour schedule and balancing between personal life and work is an essential issue in the European Union countries especially in the United Kingdom since 1990s (Jones \& Jones, 2011). This agenda has attracted the attention of various parties, especially among motivational experts and politicians who agreed that this issue should be discussed further in order to improve the balance between work and family. Indeed, the flexible working arrangement practices leads to balance the job responsibility and children's safety at home especially for working mother (Michael, 2004). Furthermore, previous research proved that the flexible working hours contributed to higher job satisfaction, motivation and employee engagement (Mc Nall et al., 2010). Therefore, to increase the employee motivation towards the vision and mission, each organization needs to emphasize on their staff welfare. Fynes et al. (1998), identified among the advantages gained by the staff through the implementation of flexible working hours are the ability to reduce absenteeism, reducing stress, improving staff moral and increasing staff motivation to work. As a result, the implementation of flexible working hours schedule in Europe in both public and private sectors have contributed to balance the work and family responsibility. By doing so, the staffs have more suitable time to cater responsibilities towards the family including food, children safety and shopping without any stress (De Roure, 1995).

The flexible working hours consists of part time, overtime, long term leaves, job sharing, flexitime and shift work (Chung \& Tijdens, 2012; Jones \& Jones, 2011). They also stated that the working time referring to the degree of flexibility, gender equity, negotiation structure and diversity of working time. However, all staff must be available at the work place within a time frame, such as within $10.00 \mathrm{am}$ until $3.30 \mathrm{pm}$. Therefore by implementing this system, employees may choose the suitable time to clock-in and clock-out, provided that the total working hours in a day or in a week remains complied (Zulkifli et al., 2004). Subramaniam and Selvaratnam (2010) pointed out that almost half of women employees in Malaysia faced difficulties of balancing work and their family life. To this regard, the government and private sectors should take note of this issue accordingly. This is because there is an increase in awareness of the quality work relationship for working mothers.

The purposed of this research is to identify the relationship between flexible working hour schedule and staff motivation in XYZ government agency. The hypothesis for this study is stated as follows:

$\mathrm{H}_{0}$ : There is no relationship between flexible working hour schedule and staff motivation level. 
$\mathrm{H}_{1}$ : There is a relationship between flexible working hour schedule and staff motivation level.

\section{Literature Review}

The impact from changes in economy, technology, social and lifestyle in today's environments have boosted the awareness of flexible working arrangements in an organisation. Evidence from the previous study indicated that the competitive working environment and increasing workload had caused family and personal life being neglected (Mary \& Chris, 1998). Smith (1993) pointed out that working women should have balance between tasks in the office and responsibility to the family especially on safety, health and children needs. Therefore, Cook (1992) suggested that through the implementation of flexible working hour's schedule, the responsibilities over children's safety and education will be more secured. This is due to the fact that they are able to engage for a better coordination between work and responsibilities to the family. This statement is than further supported by Emmott and Hutchinson (1998). They found out that the implementation of flexible working hours schedule could increase and balance women's responsibilities in work and family. It is a fact that children need love, food, safety and parents' attention to ensure that children lead to a normal life. This complies with Maslow's theory of motivation that emphasizes the aspects of safety, love, needs for food, esteem and self-actualisation that needs to be fulfilled by individual in order to increase the motivation at work.

In line with the continuous improvement initiative to uplift the service delivery system to the public, flexible working hour's schedule which is also known as Staggered Working Hours (SWH) has been implemented in the Federal Territory of Kuala Lumpur commencing $1^{\text {st }}$ May 1998. In fact, the government has agreed for the SWH to be extended to all agencies in the Federal Government throughout the country. The key objective of this policy is to increase the service quality and extend service duration to the public. In order to ensure the effectiveness of SWH, the characteristics of employees' satisfaction and motivation at work should be addressed accordingly. As such, employer should play an important role in determining employee satisfaction, comfortability and welfare. Cushway (1994) argued that the implementation of flexible working hours is an effective stage to increase productivity without increasing the work force.

\subsection{Trend in Flexible Working Hours}

Zanten (2007), the Head of Diversity and Inclusiveness Shell International pointed out that the flexible working hours is the best and most suitable option to be implemented in the company. Furthermore, he also mentioned that Shell is fortunate to be one of the world's largest companies that value environment and allows more space for women to achieve a balanced life as well as plan for women to occupy 20 per cent of senior executive positions in the company (Berita Harian, 2007). In the UK labour market for example, the flexible working hours is spreading widely (Jennifer \& Jean, 2009). Currently, the Malaysian Government's has taken effort to extend the unpaid leave for women employees in the public sector for taking care of children from currently 90 days to the maximum of five years. It has been agreed in the Cabinet meeting to give opportunity and extra time for women employees to raise their children without having to quit their job. This recent decision enables female staff to focus on bringing up children in line with the government's desire to provide attention to elementary education (Utusan Malaysia, 2007).

\subsection{Elements of Motivation}

Kreitner and Kinicki (2001) defined the motivation as a psychological process that continuously raises motivation, direction and voluntary actions towards achieving goals. Maslow argued that in every individual lives there are five hierarchical essential needs: (1) physiological; (2) safety; (3) social; (4) esteem; (5) and self-actualisation. Furthermore, he later divided the needs into lower level and higher level of needs. The lower level of needs consists of physiological, safety and social whilst higher level of needs includes esteem and self-actualisation. Managers should understand these psychological processes if they want to be successful in leading the staff towards achieving the organisational objectives. Herewith, the few elements of motivation:

1) Rewards: Everyone strives to achieve a good living. With rewards such as salary, bonus, annual leaves, pension, etc.

2) Personal objective: Human is driven to work by personal reasons and needs such as to gain basic human needs (self-preservation) which drives people to strive for their security reasons.

3) Recognition and sense of belonging: Normal human has the desire to feel needed, recognised and accepted by the society.

4) Love: When a person loves himself, his family and his employer, this will then motivates him in anything he does. He will utilise all the will power and strength to accomplish the task. 
5) Working hours: Suitable working hours are needed by the employees to have a balance between working hours and time to be spent with family and personal matters at home. The employee will feel more motivated if time spent with children at home is extended.

\section{Methodology}

In this study, the first step employed in the questionnaire designed as suggested by Churchill (1979) is to define the domain of construct. In the words of Frazer and Lawley (2000), the researcher first needs to consider the information to be included in the survey, what should be excluded from the survey and what information should be best obtained. As proposed by Churchill, Frazer and Lawley, the previous literature review was used as a principle to develop the questions. In this study, the criterion for selecting the population were carefully designed to include the positions occupied in XYZ Department. Questionnaires were sent to participants by direct visit. In order to reach the target population represented in this study, the researcher compiled a contact list with names, designations, telephone numbers and email addresses. The researcher used these contact details as references for data collection and strategies to increase the response rate. A number of 41 questionnaires were distributed to the staff of XYZ Department. The items used were based on Likert scale to facilitate the data analysis. All questions featured were guided by the research objective. In this research, the researcher plan like to study the relationship between flexible working hour schedule and staff motivation level in XYZ Department. It aimed to test the hypothesis of the relationship between the variables and the set hypothesis. Flexible working hour is the independent variable while staff motivation level is the dependent variable.

Meanwhile, in data analysis strategy, the researcher used both descriptive and inferential statistics. According to Chua (2006), inferential analysis in quantitative research is suitable for this research as a survey will be conducted to gain further response. Correlation analysis was performed to find out the relationship between the two variables. According to Sekaran (2003), correlation test is able to provide confirmation on the relationship between these two variables, that is, the flexible working hour schedule and staff motivation level. This method provides the relationship between these variables from the perspectives of direction, strength and significance of relationship. Correlation analysis is able to portray the strength of the relationship between two variables analysed, those are, dependent variable and independent variable.

Test conducted from the field indicates that the alpha value for SWH was 0.752 whilst alpha value for motivation level is at 0.762 , followed by the value for the relationship between flexible working hour schedule and staff motivation level was at 0.780 and resulted to total alpha value was at 0.862 . This pilot study was conducted to 10 staff at XYZ Department in which after obtaining the confidence interval of 0.7 then the set questionnaires were distributed to the actual respondents.

\section{Findings}

\subsection{Demographic Analysis}

Table 1 demonstrated the results based on respondents demographic. From the 41 sets of questionnaires distributed, only 38 sets were completed and returned. Overall, the majority of the respondents' age ranged from 26 to 30 years old $(39.5 \%)$ followed by 31 to 40 years old $(29 \%)$. The remaining of 10.5 per cent ranged is between the age of 21 to 25 years old and another 21 per cent is 41 years old and above.

Table 1. Demographic analysis

\begin{tabular}{lcc}
\hline Item & Frequency & Percentage \% \\
\hline Age & 4 & 10.5 \\
$21-25$ & 15 & 39.5 \\
$26-30$ & 11 & 29.0 \\
$31-40$ & 8 & 21.0 \\
41 and above & & \\
Gender & 12 & 31.6 \\
Male & 26 & 68.4 \\
Female & & \\
Marriage Status & 11 & 28.9 \\
Single & 27 & 71.1 \\
Married & 38 & 100 \\
Total & & \\
\hline
\end{tabular}


As for gender, 68.4 per cent were female and 31.6 per cent were male. Marriage status showed that the majority of the respondents were married $(71.1 \%)$ and 28.9 per cent were still single.

\section{Mean Score Analysis}

This sub section analysed all items in the questionnaire including relationship between flexible working hour and staff motivation level. Mean score values for all items were calculated and tabulated in Table 2.

Table 2. Mean score distribution analysis on relationship between flexible working hour and staff motivation level in department XYZ

\begin{tabular}{|c|c|c|}
\hline No. & Item Description & $\begin{array}{l}\text { Mean } \\
\text { score }\end{array}$ \\
\hline 1 & $\begin{array}{l}\text { I feel comfortable with the implementation of SWH compared to the normal working } \\
\text { schedule. }\end{array}$ & 3.97 \\
\hline 2 & Selection of suitable working shift (WS) allows me to spend more time with my family. & 3.82 \\
\hline 3 & $\begin{array}{l}\text { Selection of suitable working shift (WS) allows me to sort out my personal matters at home } \\
\text { without interrupting working hour. }\end{array}$ & 3.97 \\
\hline 4 & I have ample rest time to be with my family by selecting the suitable working shift (WS). & 3.87 \\
\hline 5 & Implementation of SWH is able to increase my service quality to the customer. & 3.84 \\
\hline 6 & $\begin{array}{l}\text { I feel stressed at work when my responsibilities and my children's welfare and safety at home } \\
\text { are neglected. }\end{array}$ & 3.71 \\
\hline 7 & I feel SWH helps me from being late to office. & 3.87 \\
\hline 8 & I feel that service to customer will be affected if staffs are late to work. & 3.92 \\
\hline 9 & $\begin{array}{l}\text { I feel that tardiness issue can be reduced through the implementation of SWH in all } \\
\text { departments in the government sector. }\end{array}$ & 3.84 \\
\hline 10 & I have high commitment to come to work through the implementation of SWH. & 3.87 \\
\hline 11 & $\begin{array}{l}\text { In my opinion high commitment among staff is important in strengthening the public sector } \\
\text { system. }\end{array}$ & 3.92 \\
\hline 12 & My motivation level at work can be increased through SWH. & 3.87 \\
\hline 13 & $\begin{array}{l}\text { Staff motivation level can be increased through the implementation of new policy by the } \\
\text { government such as SWH. }\end{array}$ & 3.71 \\
\hline 14 & In my opinion more time spent with the family may increase my motivation level at work. & 3.82 \\
\hline \multirow[t]{2}{*}{15} & $\begin{array}{l}\text { I found that the implementation of SWH provides more time for the customer to deal with the } \\
\text { government. }\end{array}$ & 3.82 \\
\hline & Average Mean Score & 3.85 \\
\hline
\end{tabular}

As indicated in the table above, the highest mean score was at 3.97. There were two items scored similarly in the questions on 'I feel comfortable with the implementation of SWH compared to the normal working schedule' and 'Selection of suitable working shift (WS) allows me to sort out my personal matters at home without interrupting working hour'. The lowest mean score was at 3.71 which were also being scored by two questions those are 'I feel stressed at work when my responsibilities and my children's welfare and safety at home are neglected' and 'Staff motivation level can be increased through the implementation of new policy by the government such as $S W H$ '. Subsequently, the average mean score was derived at 3.85. In conclusion, the respondents from the $X Y Z$ Department benefited from the implementation of SWH.

\subsection{Inferential Analysis}

\section{Normality test}

In order to identify the normally distributed data, a few tests can be performed by using Kolmogorov-Smirnow, Skewness and Kurtosis. Data sample were tested to determine whether it is normally distributed. 
Table 3. Normality test

\begin{tabular}{cccccc}
\hline \multicolumn{2}{c}{ Kolmogorov-Smirnov(a) } & \multicolumn{3}{c}{ Shapiro-Wilk } \\
Statistic & $\mathrm{df}$ & Sig. & Statistic & $\mathrm{df}$ & Sig. \\
\hline .125 & 38 & .139 & .973 & 38 & .473 \\
\hline
\end{tabular}

Table 3 above demonstrated that the normality test was at not significant value for Kolmogorov-Smirnov (a) $(\mathrm{p}=0.125)$ and Shapiro-Wilk $(\mathrm{p}=0.473)$. Therefore, the data in this study is normally distributed as the significant values for both Kolmogorov-Smirnov (a) and Shapiro-Wilk shown significant values of more than 0.05 respectively.

\section{Correlation Test}

Correlation test analysis depicts the strength of the relationship existed between dependent and independent variables.

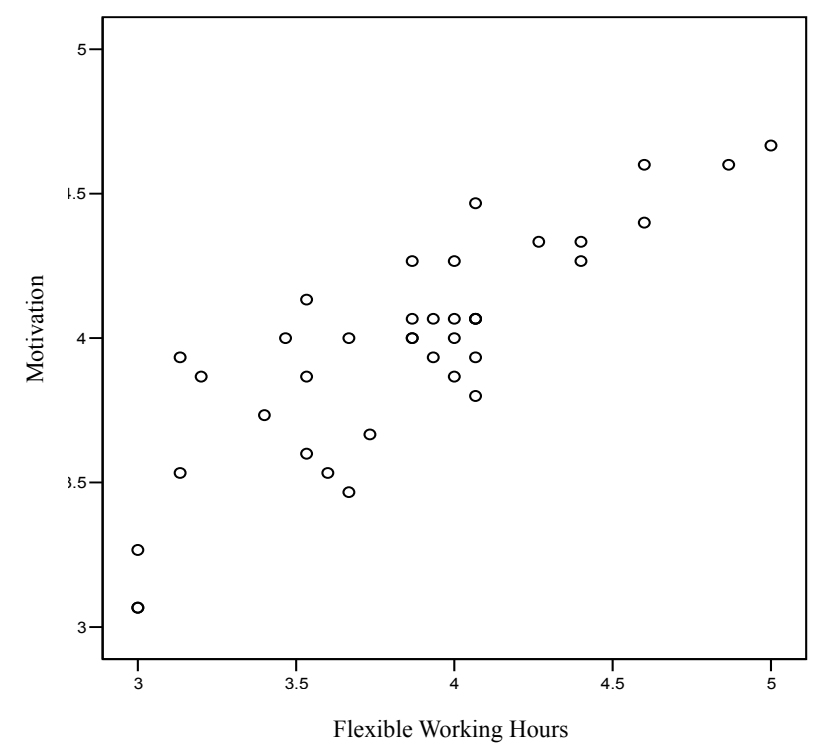

Figure 1. Relationship between independent and dependent variables

As shown in Figure 1, the relationship between dependent and independent variables is strong. Axis Y represents staff motivation level as the dependent variable and $\mathrm{X}$ is the flexible working hour schedule being the independent variable. A strong relationship is indicated by the plotted data that skewed towards the right side, explaining the positive relationship.

\section{Pearson correlation test}

In this study, the correlation analysis was used to investigate the relationship between the flexible working hours and staff motivation. 
Table 4. Pearson correlation test

\begin{tabular}{|c|c|c|c|c|}
\hline & & & $\begin{array}{l}\text { Flexible Working Hour } \\
\text { Schedule }\end{array}$ & $\begin{array}{l}\text { Staff Motivation } \\
\text { Level }\end{array}$ \\
\hline \multirow[t]{3}{*}{$\begin{array}{l}\text { Flexible } \\
\text { Schedule }\end{array}$} & Hour & $\begin{array}{l}\text { Pearson } \\
\text { Correlation }\end{array}$ & 1 & $.841(* *)$ \\
\hline & & Sig. (2-tailed) & . & .000 \\
\hline & & $\mathrm{N}$ & 38 & 38 \\
\hline \multirow[t]{3}{*}{ Staff Motivation Level } & & $\begin{array}{l}\text { Pearson } \\
\text { Correlation }\end{array}$ & $.841(* *)$ & 1 \\
\hline & & Sig. (2-tailed) & .000 & \\
\hline & & $\mathrm{N}$ & 38 & 38 \\
\hline
\end{tabular}

** Correlation is significant at the 0.01 level (2-tailed).

$\mathrm{H}_{0} \rho=0$

$\mathrm{H}_{\mathrm{A}} \rho \neq 0$

Sig $=0.000, \mathrm{r}_{\mathrm{s}}=0.841$

According to table above the coefficient value is significant and is marked with the symbol $\left(^{*}\right)$. The results show that all coefficient correlation was at the significance level of $p=0.000$ level. This result indicated that the coefficient correlation value $(\rho)$ is different from zero by subtracting $\mathrm{H}_{0}$ as the significance value is lesser than 0.01 .

Table 5. Interpretation of coefficient correlation value

\begin{tabular}{ll}
\hline \multicolumn{1}{c}{ Coefficient Correlation Value $(\mathrm{r})$} & \multicolumn{1}{c}{ Interpretation } \\
\hline Less than 0.20 & Very weak relationship \\
$0.20-0.40$ & Low correlation \\
$0.40-0.70$ & Moderate correlation \\
$\mathbf{0 . 7 0}-\mathbf{0 . 9 0}$ & Strong correlation \\
$0.90-1.00$ & Very strong correlation \\
\hline
\end{tabular}

Source: Chua (2006)

As indicated in the table above, the relationship between the independent and dependent variables are strongly correlated $\left(r_{s}=0.841\right)$. Generally, the value of $r$ enables the percentage of differences in $Y$ to be identified, as described by its relationship with $X$, through $100 r^{2}$. As such, if the derived coefficient is 0.841 , then $70.73 \%[100 \%$ $\times\left(0.841^{2}\right)$ ] from differences in $Y$ is the result of its relationship with $X$.

\section{Discussion and Recommendations}

The results from this research confirmed that the implementation of flexible working hour schedule contributed to the staff motivation at XYZ Department. Hence, this study further supports the previous researches conducted on the perspectives of female staff satisfaction through flexible working hour, which proved could increase the motivation and satisfaction level of a family (Emmott and Hutchinson, 1998). Nevertheless, the implementation of flexible working hour schedule allows staff to perform duties in a comfortable, peaceful and less stress condition that can elevate staff motivation level. This study than further supports the previous research findings indicated that there is relationship between the implementation of flexible working hour schedule and staff motivation level at XYZ Department. Simultaneously, SWH enables the staff to balance between their obligations at work and family matters at home. Following the conducted research, it is clearly indicated that the implementation of SWH may give positive impact to married staffs. This is proven from Smith (1993) that working women should have a balance between tasks in the office and her obligation towards the family especially on safety issues, health and her children's needs for food. In other research, Cook (1992) concluded 
that through the implementation of flexible working hour schedule the obligations towards children's safety and early education are more secured and both responsibilities at work and at home can be streamlined.

From another point of view, the implementation of SWH could also reduce the absenteeism and improve staff moral and motivation level (Fynes at al., 1998). The mean score indicated in this study was more than 3 indicated that they agreed with the statement. This is due to the fact that SWH implementation enables staff to choose the best time to clock-in and clock-out. They will have more benefit with the implementation of this flexible time arrangement. For example, for the family employees they are able to find a more suitable time for the needs of safety, health and kid's education. From the research outcome, the basic needs such as staff needs for meal and ample break time strongly influence ones motivation to work.

This study indicated that there is a relationship between flexible working hours schedule and staff motivation in $X Y Z$ Department. As such, it is recommended for XYZ Department to increase staff motivation level through the implementation of SWH by the Federal Government. In the meantime, the XYZ Department senior officers and heads of department should provide brief information to the staff on SWH system in general to ensure they understand the system thoroughly. This is for the reason that the results indicated showed there is still staff who do not actually understand the implementation of SWH by the government. Apart from that, the Head of XYZ Department should balance the number of staff for each Staggered Hour (SH) selections to ensure smooth office operations especially the counter service for customers.

From the researcher's opinion, XYZ Department staff should identify appropriate SH in order to allow staff to have ample time with their family hence boost their passion and motivation to work. According to Riedmann (2006), selection of suitable clock-in and clock-out time every day may give them ample time to be with their family and able to meet the needs especially on safety, health and children's needs for meal. Apart from that, staff at XYZ Department should have high internal attributes such as self-discipline, responsible, trustworthy and commitment towards their work to ensure effective implementation of SWH. This is because the comments gathered from many respondents stated that without practicing these values all implemented policies and strategies by the Federal Government may not be successful. As such, the employees need to play an important role and give full cooperation to the employer to implement the SWH system successfully in the XYZ Department.

Moreover the Federal Government should monitor closely the SWH implementation to ensure the effectiveness of this policy. Apart from that, the government need to form a special committee to study the effectiveness of SWH implementation throughout the Federal Government agencies in the nation. Through this committee, all complications and problems voiced out by the staff can be addressed drastically to ensure the effectiveness of SWH system implementation. Besides that, the Government should consider improvements on the SWH system such as regular assessments on effectiveness of SWH implementation. For instance every department of the Federal Government agencies must submit staff performance report for every six month. This approach will assist the government to provide room for improvement in order to maintain the effectiveness of SWH system implementation throughout the nation.

This study was conducted to achieve the set objectives. Future researchers may consider to:

1) Extended the research. Future researchers are expected to extend the study by increase number of samples. With that, the findings shall be more accurate. Future researchers may use different method of sampling for data collection

2) Make research comparison: This research may also be conducted by performing comparison between relationship of Flexible working hour schedule and staff motivation level in XYZ Department and similar parameters at the federal level. This is due to differences of motivation level for staff at different branches.

3) Extend the studied scope: Subsequently, the researchers may extend the scope of studies as it is not limited on certain departments only.

\section{Conclusion}

Nowadays, the concept of flexible working arrangements is becoming very common as well as universal strategies to be implemented in government and private organisation. The changes of workplace and job today may result in enhancing the employees work satisfaction and motivation. Consequently, it is important for the organisation to provide more attention on this policy. In addition, the organizations should also perceive the implementation of the flexible working arrangement from a broader perspective. This is because the studies of alternating working hours portray impact on work life conflict and health. 


\section{References}

Chua, Y. P. (2006). Kaedah dan Statistik Penyelidikan: Asas Statistik Penyelidikan (2nd ed.). Malaysia: McGraw-Hill Education.

Chung, H., \& Tijdens, K. (2012). Working time flexibility components and working time regimes in Europe: using company-level data across 21 countries.

Cook, A. (1992). Can Work Requirements Accommodate the Needs of Dual Earner Families. In S. Lewis, \& H. Hootmans (Eds.), Dual-Earner Families: International Perspectives. Sage Publication, London.

Cushway, B. (1994). Flexible Working Practices: The Controversy and Evidence. In C. Brewster, \& A. Hegewisch (Eds.), Policy and Practicein Earopean Human Resource Management. London.

DeRoure, F. (1995). Reconciliation of Family and Work. Workshop Proceeding on the Reconciliation of Family and Work held in the Pantion University, Athens.

Emmott, H., \& Hutchinson A. (1998). Balancing Work and Flexible Working: Employer Benefit from Flexible Working. Department of Social and Family Affair.

Fynes, N., \& Storrie, A. (1998). Families and Work in the Twenty-first Century: Employer Benefit from Flexible Working. Department of Social and Family Affair.

Harian, B. (2007). Waktu Kerja Anjal Pilihan Terbaik. September 12. p 20.

Jennifer, T., \& Jean, G. (2009). Organisational approaches to flexible working: Perspectives of equality and diversity managers in the UK. Equal Opportunities International, 28(8), 671. http://dx.doi.org/10.1108/02610150911001706

Jones, K., \& Jones, E. (2011). Flexible Working Practices in the UK: Gender and Management Perspectives. Journal of Women in Society, 2, 1-8.

Mary, C., \& Chris, B. (1998). Identifying good practice in flexible working. Employee Relations, 20(5), 490-503. http://dx.doi.org/10.1108/01425459810238792

Maslow. (1954). Human Resource Management Practice (8th ed.). Great Britain: The Bath Press.

McClelland. (2003). Principle Management Practice (8th ed.). Great Britain: The Bath Press.

McNall, L. A., Masuda, A. D., \& Nicklin, J. M. (2010). Flexible Work Arrangements, Job Satisfaction, and Turnover Intentions: The Mediating Role of Work-to-Family Enrichment. The Journal of Psychology, 144(1), 61-81. http://dx.doi.org/10.1080/00223980903356073

Micheal, F. (2004, May). Flexibility at Work. Paper Presented at the Conference on Flexible Working Patterns, French Institute, Athens.

Ooi, Y. K., Aziz, Z., Ahmad, F., \& Razak, H. A. (2004). Gelagat Organisasi (2nd ed.). Open University Malaysia: Meteor Doc.

Riedmann, A. (2006). Working time and work-life balance in European companies: Establishment Survey on Working Time 2004-2005: Office for Official Publications of the European Communities.

Sekaran, U. (2003). Research Method for Business: A Skill Building Approach (4th ed.). Clementi Loop, Singapore: John Wiley and Sons, Inc.

Smith, H. (1993). Balancing Work and Flexible Working: Employer Benefit from Flexible Working. Department of Social and Family Affair.

Subramaniam, G., \& Selvaratnam, D. P. (2010). Family Friendly Policies in Malaysia: Where Are We? Journal of International Business Research, 9(1), 43-55.

Utusan Malaysia. (2007). Wanita Berhenti Bekerja Kerja Lebih Banyak Hadapi Kesukaran. September 12. p 19.

Wareing, A. (1992). Working arrangements and patterns of working hours in Britain. Employment Gazette, 100(3), 88-100.

Zulkufli, A, Ooi, Y. K., Faiz, A., \& Hanissah, A. R. (2004). Gelagat Organisasi (2nd ed.). Open University Malaysia: Meteor Doc. 